\title{
Is the alternative medicine a real alternative in adult atopic dermatitis? Experiences of 125 patients
}

\author{
Gyorgyi Ponyai*, Erzsebet Temesvari and Sarolta Karpati \\ Department of Dermatology, Venerology and Dermatooncology, Semmelweis University, Budapest, Hungary
}

\begin{abstract}
Introduction: The prevalence of adulthood Atopic Dermatitis (AD) is increasing worldwide. AD patients tend to prefer Alternative Therapy (AT), despite the lack of evidence-based results. While the effect of AT is usually placebo-equal, it's unexpected or harmful side-effects have alredy been documented.

Aim: Aim of the study was to map the frequency of using AT among adult AD patients, to list the most common AT and to collect the patients' own experiences about the tried methods. A total of 125 adult AD patients (91 women, 34 men, range: $18-66$ years) were involved in this study. Data regarding the tried AT were collected retrospetively.

Results: 67 patients (54\%) tried at least one AT to treat their AD. Some patients tried more AT, the 67 patients had 104 attempts in all. Most popular AT were homeopathy (34\%), aloe vera products (27\%), herb brews (18\%), and acupuncture (15\%). According to patients' observation skin symptoms of 8 patients (12\%) improved after using some AT, while 8 patients' (12\%) skin symptoms failed by using AT. As reported by the patients, most of the attempts (86/104, $83 \%)$ were inefficient.
\end{abstract}

Conclusion: According to our data, most of the adult patients have unsatisfying experiences with the vast majority of the tried AT in the therapy of AD symptoms. Both the high number of patients trying these methods and the inefficient attempts are noteworthy.

\section{Introduction}

Atopic dermatitis is a chronic, pruritic, inflammatory skin disease, that affects mostly children, but also many adults. The prevalence of $\mathrm{AD}$ is increasing worldwide. The prevalence of adulthood $\mathrm{AD}$ is $1-3 \%$ at present, the number of adult cases may increase further [1-5]. Many patients do not accept the genetic determination and chronic-recurring course of AD. They become dissatisfied with the conventional medical treatment or are afraid of side-effects of particular drugs (steroidphobia). These patients turn often to AT. The efficacy of alternative methods is often based on lay informations. The application and the doses are not standardised Of the applied therapies, homeopathy, acupuncture and herbs are the most common. The majority of these methods are inefficient, dangerous side-effects may occur [3,6-9].

\section{Patients and methods}

In our study 125 adult $\mathrm{AD}$ patients (P)/91 women (73\%) and 34 men $(27 \%)$ / were involved from our Atopic Department. The diagnosis of $\mathrm{AD}$ based on the Hanifin- Rajka criteria [1-4,8]. The youngest patient was 18, the oldest was 66 years old at the time of the study. The average age was 28 years. Data according the tried alternative methods, patients' experiencies and observations were documented. Patients were asked to list the AT tried for the therapy of their AD in the past. They were asked to value the effect of the AT on the skin status: symptoms improved (IP) (itching or/and erythema and dryness becoming milder); worsed (W); or the AT was inefficient (IE).

The work has been approved by the ethical committees related to the institution in which was performed and the subjects gave informed consent to the work.

\section{Results}

\section{Alternative therapies, methods used by adult AD patients}

Among the 125 patients 58 patients (46\%) didn't use any AT for the treatment of AD symptoms, 67 patients (54\%) used at least one AT: 52 women ( $57 \%$ of the women) and 15 men ( $44 \%$ of the men). Some patients tried more AT; the 67 patients had a total of 104 attempts. The maximum number of the attempts (methods or therapies) tried by one patient was seven (P25) (Table 1).

The applied AT were homeopathy, aloe vera products, herb brews (chinese, soothing, detoxifying, lymphatic system detox teas), acupuncture, Bioptron lamp, naturopathy (reflexology, energy transfer, bioresonance), local herb preparations (calendula cream, mixed herb cream, camomile pack), supplementaries and diets (sea-buckthorn, fish oil, immunity booster, oiltree extract, algae and cranberry capsules), per os herb extracts (calendula and green barley extract, grapefruit drops, ginzeng), herb soaps (calendula and tea tree soap), liquid diet (carrot and beet juice), yoga and meditation (Table 2).

Correspondence to: Györgyi Pónyai MD. PhD. Dermato-allergologist, Department of Dermatology, Venerology and Dermatooncology, Faculty of Medicine, Semmelweis University, 1085 -Budapest, Maria u. 41, Hungary; E-mail: gyorgyi.ponyai@gmail.com

Key words: adult atopic dermatitis, alternative therapy, homeopathy, hypnosis, Traditional Chinese Medicine, herb therapy, acupuncture

Received: August 08, 2015; Accepted: September 25, 2015; Published: September 28, 2015 
Table 1. AT tried by adult patients for AD symptoms.

F: female, M: male, IE: inefficient, W: worsed, IP: improved

\begin{tabular}{|c|c|c|c|c|}
\hline & Sex & Age & Alternative therapy & $\begin{array}{c}\text { Patient's own } \\
\text { observation }\end{array}$ \\
\hline 1 & $\mathrm{~F}$ & 21 & aloe vera products & IE \\
\hline 2 & M & 18 & - & \\
\hline 3 & $\mathrm{~F}$ & 28 & - & \\
\hline 4 & $\mathrm{~F}$ & 19 & - & \\
\hline 5 & $\mathrm{~F}$ & 35 & - & \\
\hline 6 & $\mathrm{~F}$ & 30 & - & \\
\hline 7 & $\mathrm{~F}$ & 24 & homeopathy & IE \\
\hline 8 & M & 29 & - & \\
\hline 9 & $\mathrm{~F}$ & 27 & - & \\
\hline \multirow[t]{2}{*}{10} & M & 31 & sea-buckthorn capsules & $\mathrm{W}$ \\
\hline & & & aloe vera products & IE \\
\hline 11 & $\mathrm{~F}$ & 52 & homeopathy & IE \\
\hline 12 & $\mathrm{~F}$ & 23 & camomile pack & IE \\
\hline 13 & $\mathrm{~F}$ & 24 & - & \\
\hline 14 & $\mathrm{~F}$ & 56 & local herbs & IE \\
\hline 15 & M & 23 & - & \\
\hline \multirow[t]{4}{*}{16} & M & 26 & homeopathy & $\mathrm{W}$ \\
\hline & & & chinese tea & IE \\
\hline & & & fish oil capsules & IE \\
\hline & & & acupuncture & IE \\
\hline 17 & M & 40 & - & \\
\hline 18 & $\mathrm{~F}$ & 35 & - & \\
\hline 19 & M & 22 & - & \\
\hline 20 & $\mathrm{~F}$ & 22 & - & \\
\hline 21 & $\mathrm{~F}$ & 28 & green barley extract & IE \\
\hline 22 & F & 31 & grapefruit drops & IE \\
\hline 23 & $\mathrm{~F}$ & 25 & homeopathy & IE \\
\hline 24 & $\mathrm{~F}$ & 27 & - & \\
\hline \multirow[t]{6}{*}{25} & M & 18 & calendula soap & IE \\
\hline & & & teatree soap & IE \\
\hline & & & aloe vera products & IE \\
\hline & & & „immunity booster” capsules & IE \\
\hline & & & „,detoxifying” tea & IE \\
\hline & & & „lymphatic system detox" tea & IE \\
\hline 26 & $\mathrm{~F}$ & 62 & - & \\
\hline \multirow[t]{2}{*}{27} & $\mathrm{~F}$ & 21 & Bioptron lamp & IP \\
\hline & & & Calendula extract & IE \\
\hline 28 & $\mathrm{~F}$ & 19 & - & \\
\hline 29 & $\mathrm{~F}$ & 27 & - & \\
\hline 30 & M & 25 & - & \\
\hline \multirow[t]{2}{*}{31} & $\mathrm{~F}$ & 32 & homeopathy & IE \\
\hline & & & aloe vera products & IE \\
\hline
\end{tabular}

\begin{tabular}{|c|c|c|c|c|}
\hline 32 & $\mathrm{~F}$ & 21 & - & \\
\hline 33 & M & 28 & acupuncture & IP \\
\hline \multirow[t]{2}{*}{34} & $\mathrm{~F}$ & 37 & beet juice & IE \\
\hline & & & carrot juice & IE \\
\hline 35 & $\mathrm{~F}$ & 20 & - & \\
\hline 36 & $\mathrm{~F}$ & 52 & aloe vera products & IE \\
\hline 37 & $\mathrm{~F}$ & 27 & acupuncture & $\mathrm{W}$ \\
\hline 38 & $\mathrm{~F}$ & 33 & - & \\
\hline 39 & $\mathrm{~F}$ & 21 & aloe vera products & IE \\
\hline 40 & $\mathrm{~F}$ & 20 & Bioptron lamp & IE \\
\hline 41 & $\mathrm{~F}$ & 21 & aloe vera products & IE \\
\hline 42 & $\mathrm{~F}$ & 30 & - & \\
\hline 43 & M & 40 & - & \\
\hline 44 & $\mathrm{~F}$ & 28 & - & \\
\hline \multirow[t]{3}{*}{45} & M & 26 & calendula extract & IE \\
\hline & & & herb brews & IE \\
\hline & & & homeopathy & IE \\
\hline 46 & $\mathrm{~F}$ & 29 & aloe vera products & IE \\
\hline \multirow[t]{2}{*}{47} & $\mathrm{~F}$ & 20 & homeopathy & IE \\
\hline & & & acupuncture & IE \\
\hline 48 & $\mathrm{~F}$ & 25 & - & \\
\hline 49 & $\mathrm{~F}$ & 24 & yoga & IE \\
\hline 50 & $\mathrm{~F}$ & 27 & herb brews & IE \\
\hline 51 & $\mathrm{~F}$ & 25 & mixed herb cream & $\mathrm{IE}$ \\
\hline 52 & $\mathrm{~F}$ & 21 & homeopathy & $\mathrm{IE}$ \\
\hline 53 & $\mathrm{~F}$ & 22 & - & \\
\hline 54 & $\mathrm{~F}$ & 28 & - & \\
\hline 55 & $\mathrm{~F}$ & 47 & homeopathy & $\mathrm{IE}$ \\
\hline \multirow[t]{4}{*}{56} & $\mathrm{~F}$ & 25 & Aloe vera products & W \\
\hline & & & herbl brews & $\mathrm{IE}$ \\
\hline & & & acupuncture & IE \\
\hline & & & „energy transfer" & $\mathrm{IE}$ \\
\hline 57 & M & 23 & - & \\
\hline 58 & $\mathrm{~F}$ & 28 & homeopathy & $\mathrm{IE}$ \\
\hline 59 & $\mathrm{~F}$ & 20 & - & \\
\hline \multirow[t]{3}{*}{60} & $\mathrm{~F}$ & 34 & acupuncture & IE \\
\hline & & & juice fasting & IE \\
\hline & & & meditation & $\mathrm{IE}$ \\
\hline 61 & $\mathrm{M}$ & 29 & „soothing" tea & $\mathrm{IE}$ \\
\hline 62 & $\mathrm{M}$ & 23 & herb extract & $\mathrm{IE}$ \\
\hline 63 & M & 19 & - & \\
\hline 64 & $\mathrm{~F}$ & 40 & 一 & \\
\hline 65 & $\mathrm{~F}$ & 24 & homeopathy & $\mathrm{IE}$ \\
\hline 66 & $\mathrm{M}$ & 26 & - & \\
\hline 67 & $\mathrm{M}$ & 30 & aloe vera products & $\mathrm{IE}$ \\
\hline 68 & $\mathrm{~F}$ & 21 & - & \\
\hline
\end{tabular}




\begin{tabular}{|c|c|c|c|c|}
\hline 69 & $\mathrm{~F}$ & 21 & Bioptron lamp & IP \\
\hline \multirow[t]{2}{*}{70} & $\mathrm{~F}$ & 27 & aloe vera products & IE \\
\hline & & & homeopathy & IE \\
\hline 71 & $\mathrm{~F}$ & 24 & plantar massage & IE \\
\hline 72 & $\mathrm{~F}$ & 24 & aloe vera products & IE \\
\hline 73 & $\mathrm{~F}$ & 34 & - & \\
\hline 74 & $\mathrm{~F}$ & 33 & - & \\
\hline \multirow{2}{*}{75} & $\mathrm{~F}$ & 19 & Bioptron lamp & IE \\
\hline & & & soap of herbs & IE \\
\hline 76 & $\mathrm{~F}$ & 35 & calendula cream & IE \\
\hline 77 & $\mathrm{~F}$ & 24 & - & \\
\hline 78 & $\mathrm{~F}$ & 38 & - & \\
\hline 79 & $\mathrm{M}$ & 28 & homeopathy & IE \\
\hline 80 & $\mathrm{~F}$ & 54 & aloe vera products & IE \\
\hline 81 & $\mathrm{~F}$ & 25 & Bioptron lamp & IE \\
\hline 82 & $\mathrm{M}$ & 32 & herb brews & IE \\
\hline 83 & $\mathrm{~F}$ & 22 & homeopathy & IE \\
\hline 84 & $\mathrm{~F}$ & 27 & - & \\
\hline 85 & $\mathrm{~F}$ & 21 & mixed herb cream & IE \\
\hline 86 & $\mathrm{~F}$ & 25 & calendula cream & IE \\
\hline 87 & $\mathrm{~F}$ & 21 & - & \\
\hline 88 & $\mathrm{~F}$ & 34 & - & \\
\hline 89 & $\mathrm{M}$ & 21 & - & \\
\hline 90 & $\mathrm{M}$ & 18 & - & \\
\hline 91 & $\mathrm{M}$ & 23 & - & \\
\hline \multirow[t]{2}{*}{92} & $\mathrm{~F}$ & 27 & homeopathy & $\mathrm{W}$ \\
\hline & & & oiltree extract capsules & IE \\
\hline 93 & $\mathrm{~F}$ & 30 & algae capsules & IP \\
\hline 94 & $\mathrm{M}$ & 35 & - & \\
\hline 95 & $\mathrm{M}$ & 22 & „bioresonance” & IE \\
\hline 96 & $\mathrm{M}$ & 32 & herb brews & IP \\
\hline \multirow[t]{2}{*}{97} & $\mathrm{~F}$ & 21 & homeopathy & $\mathrm{W}$ \\
\hline & & & Bioptron lamp & IP \\
\hline \multirow[t]{3}{*}{98} & $\mathrm{~F}$ & 20 & homeopathy & $\mathrm{W}$ \\
\hline & & & calendula cream & $\mathrm{W}$ \\
\hline & & & acupuncture & IP \\
\hline 99 & $\mathrm{~F}$ & 42 & aloe vera products & W \\
\hline \multirow[t]{2}{*}{100} & $\mathrm{~F}$ & 30 & aloe vera products & $\mathrm{IE}$ \\
\hline & & & ginzeng & IE \\
\hline \multirow[t]{3}{*}{101} & $\mathrm{~F}$ & 29 & homeopathy & IE \\
\hline & & & acupuncture & IE \\
\hline & & & "energy transfer" & IE \\
\hline 102 & $\mathrm{~F}$ & 20 & homeopathy & IE \\
\hline 103 & $\mathrm{~F}$ & 22 & - & \\
\hline 104 & $\mathrm{M}$ & 20 & Bioptron lamp & IE \\
\hline 105 & $\mathrm{~F}$ & 25 & herb brews & IE \\
\hline
\end{tabular}

\begin{tabular}{|c|c|c|c|c|}
\hline 106 & F & 29 & - & \\
\hline 107 & $\mathrm{~F}$ & 20 & - & \\
\hline 108 & F & 23 & - & \\
\hline 109 & $\mathrm{~F}$ & 57 & - & \\
\hline 110 & M & 66 & - & \\
\hline 111 & M & 23 & - & \\
\hline 112 & M & 27 & - & \\
\hline 113 & $\mathrm{~F}$ & 26 & herb brews & IE \\
\hline \multirow[t]{2}{*}{114} & M & 30 & homeopathy & IE \\
\hline & & & aloe vera products & IE \\
\hline \multirow[t]{4}{*}{115} & F & 33 & homeopathy & IE \\
\hline & & & acupuncture & IE \\
\hline & & & plantar massage & IE \\
\hline & & & "naturopathy" & IE \\
\hline 116 & $\mathrm{M}$ & 25 & - & \\
\hline \multirow[t]{2}{*}{117} & $\mathrm{~F}$ & 29 & homeopathy & IE \\
\hline & & & plantar massage & IE \\
\hline \multirow[t]{2}{*}{118} & $\mathrm{~F}$ & 22 & homeopathy & IE \\
\hline & & & cranberry capsules & IE \\
\hline 119 & $\mathrm{~F}$ & 19 & - & \\
\hline \multirow[t]{2}{*}{120} & $\mathrm{~F}$ & 41 & acupuncture & IP \\
\hline & & & aloe vera products & IP \\
\hline 121 & $\mathrm{~F}$ & 20 & - & \\
\hline 122 & $\mathrm{~F}$ & 18 & - & \\
\hline \multirow[t]{2}{*}{123} & $\mathrm{~F}$ & 31 & herb brews & IE \\
\hline & & & aloe vera products & IE \\
\hline 124 & $\mathrm{~F}$ & 25 & - & \\
\hline 125 & $\mathrm{~F}$ & 26 & - & \\
\hline
\end{tabular}

Table 2. Frequency of AT tried by adult AD patients.

\begin{tabular}{|l|c|c|}
\hline Method & $\begin{array}{c}\text { No. of patients, } \\
\text { tried this method }\end{array}$ & $\begin{array}{c}\text { \% of patients } \\
\text { tried AT (n= 67) }\end{array}$ \\
\hline homeopathy & 23 & $34 \%$ \\
\hline aloe vera products & 18 & $27 \%$ \\
\hline herb brews & 12 & $18 \%$ \\
\hline acupuncture & 10 & $15 \%$ \\
\hline Bioptron lamp & 7 & $10 \%$ \\
\hline naturopathy & 7 & $10 \%$ \\
\hline local herbs & 7 & $10 \%$ \\
\hline supplementary, diets & 6 & $9 \%$ \\
\hline per os herb extracts & 6 & $9 \%$ \\
\hline herb soap & 3 & $4.5 \%$ \\
\hline liquid diet & 3 & $4.5 \%$ \\
\hline yoga, meditation & 2 & $3 \%$ \\
\hline
\end{tabular}




\section{Patients' observations according to the efficacy of the alternative methods and therapies}

According to the patients' observations, improvement of the skin symptoms (itching or/and erythema and dryness becoming milder) was reported by $8 / 67$ patients (12\%) due to the listed AT (Table 3 ). It means 9 attemps out of 104 (8.6\%): Bioptron lamp (P27, P69, P97), acupuncture (P33, P98, P120), herb brews (P96), supplementaries and diets - algae capsules (P93), and aloe vera product (P120).

Worsening of the AD symptoms was reported by 8 patients (12\%), it means 9 attempts out of the 104 (8.6\%): homeopathy (P16, P92, P97, P98), aloe vera products (P56, P99), acupuncture (P37), supplementaries and diets - sea-buckthorn capsules (P10), calendula cream (P98) (Table 4).

Most of the patients reported inefficiency of the AT tried for AD symptoms (86/104 attempts $83 \%$ were inefficient). The most common inefficient methods were: homeopathy, aloe vera products and herb brews (Table 5).

Table 3. Effective therapies reported by adult $\mathrm{AD}$ patients

\begin{tabular}{|l|c|c|}
\hline Therapy & $\begin{array}{c}\text { No. of patients, } \\
\text { reported improvement }\end{array}$ & $\begin{array}{c}\text { \% of patients } \\
\text { tried AT (n= 67) }\end{array}$ \\
\hline Bioptron lamp & 3 & 7 \\
\hline acupuncture & 3 & 10 \\
\hline herb brews & 1 & 12 \\
\hline supplementary, diet & 1 & 6 \\
\hline aloe vera products & 1 & 18 \\
\hline
\end{tabular}

Table 4. Flare up of AD symptoms by using AT reported by the patients.

\begin{tabular}{|l|c|c|}
\hline Therapy & $\begin{array}{c}\text { No. of patients, } \\
\text { reported flare up }\end{array}$ & $\begin{array}{c}\text { \% of patients } \\
\text { tried AT (n= 67) }\end{array}$ \\
\hline homeopathy & 4 & 23 \\
\hline aloe vera products & 2 & 18 \\
\hline acupuncture & 1 & 10 \\
\hline supplementary, diet & 1 & 6 \\
\hline local herbs & 1 & 7 \\
\hline
\end{tabular}

Table 5. Inefficient AT according to the observations of adult AD patients.

\begin{tabular}{|l|c|c|}
\hline Therapy & $\begin{array}{c}\text { No. of patients, } \\
\text { reported inefficiency }\end{array}$ & $\begin{array}{c}\text { No. of patient, tried } \\
\text { this method }\end{array}$ \\
\hline homeopathy & 19 & 23 \\
\hline aloe vera products & 15 & 18 \\
\hline herb brews & 11 & 12 \\
\hline naturopathy & 7 & 7 \\
\hline acupuncture & 6 & 10 \\
\hline local herbs & 6 & 7 \\
\hline per os herb extracts & 6 & 6 \\
\hline Bioptron lamp & 4 & 6 \\
\hline supplementary, diet & 4 & 3 \\
\hline herb soap & 3 & 3 \\
\hline liquid diet & 3 & 2 \\
\hline yoga, meditation & 2 & 2 \\
\hline yoga, meditation & 2 & 7 \\
\hline
\end{tabular}

Alternative therapies and methods are very popular all over the world; in the dermatological practice mostly among patients with $\mathrm{AD}$, acne and psoriasis $[6,7,9,10]$. Atopic dermatitis is a chronic, itching skin disease and conventional medical threapies give sometimes inadequate symptom management. Patients are often disappointed and turn to alternative solutions. About a half of all AD patients try AT $[7,11]$. It is a popular misbelief that natural methods do not have any side effects. Patients do not consider alternative treatments to be medicines in the traditional sense of the word. The results are conradictory, contolled studies are rare or lacking [3,7,10-12].

The most common AT in the general population are homeopathy, acupuncture, diets and supplemetaries, massages, aroma therapy and herb remedies (teas, capsules, creams, oils and inhalation sprays). In Japan the herb treatments, in the USA diets and vitamins and in Europe homeopathy products are very popular. Most of the methods have no effect at all. There are only few data supporting the efficacy of alternative therapies tried for adult $\mathrm{AD}$ [2,6,7,10-12].

Homeopathy is presented as one of the main AT both in the medical literature and lay magazines. Although the number of people trying homeopathy has been increased continously, the randomised, placebo controlled studies are missing. Searches involve only few patients and brought so far contradictory results. Most of the patients using homeopathy are women and suffer from chronic diseases (migrene, $\mathrm{AD}$, asthma, allergic rhinitis). In many studies are the methods of poor quality, they give few evidence for the use of homeopathy for the treatment of $\mathrm{AD}[4,11,13,14]$.

There are very few reports on the efficacy of homeopathy in adult $\mathrm{AD}$. Itamura et al. reported that homeopathy resulted improving of skin symptoms and quality of life of adult AD patients: sleep disturbances relieved, itching decreased $[14,15]$. Besides favourable results, authors note that very few controlled data and clinical tests are available about the real efficacy of homeopathy in skin diseases. Placebo controlled investigations are missing $[4,8,14,15]$.

Food is a relevant provoking factor in $35-40 \%$ of $\mathrm{AD}$ children, but only in $1-2 \%$ of adult patients. If an adult $\mathrm{AD}$ patient observes the worsening of skin symptoms after food consumption, one should first consider a pollen associated cross reaction [16-20]. The itch- and dermatitis-provoking effect of biogen amins (eg. in red wine, cheese) is well-known [22]. Some authors reported the effects of low calory diets in adult AD. According to the results of Nakamura et al. [21] and Tanaka et al. [22] low calory diet resulted the improvement of skin symptoms: itching, and the sleep disturbance becoming milder. A significant decrease of the SCORAD index, LDH5 activity, eosinophil number, peripherial NK activity and neutrofil number and PGE2 synthesis of monocytes was shown. The serum total IgE did not decrease significantly, and the allergen specific IgE values did not change. The synthesis rate of IL $4 / \mathrm{IFN} \gamma$ increased [22]. Kim et al. reported 7 adult $\mathrm{AD}$ patients with refractory skin symptoms treated with detoxification combining fasting with fluid therapy [23]. The findings are thoughtprovoking, yet due to the low number of reported patients, a clear correlation between short or long-term fasting and an improvement of $\mathrm{AD}$ symptoms cannot be shown - further controlled investigations are necessary to confirm it.

In up to $70 \%$ of $\mathrm{AD}$ patients (mainly women) emotional events and stress are responsible for the worsening of skin symptoms [2426]. In atopics stress causes a temporary rise of eosinophil count in the 
peripheral blood; IgE, IFN $\gamma$ and IL-5 levels increase too, whereas that of cortizol decreases [26]. The interpretation of stress is very subjective, anxiety, frustration, aggression may lead to a flare up of dermatitis in adults. The disease itself may be also a stress factor. Due to the visible skin symptoms stigmatisation, partnership and existential problems may occur. Autogen training, relaxation techniques, behaviour, family, group and art therapies can support the dermatological treatments $[25,26]$. According to the interesting study results of Kimata [27,28], a relaxed, good mood is useful for atopic patients.

Hypnosis has been used in medicine since ancient times. In dermatology it is not widespread, it is mainly used for pain and itch relief and to treat verruca [24]. Since AD patients are disposed for anxiety, theoretically, hypnosis may be a solution for detecting and dissolving the scratch-and-itch circle. There are very few publicated data on the efficacy of hypnosis in adult AD. According to the results of Stewart et al. [29] the itch, scratch, sleep disturbances and tension decreased significantly by hypnotherapy of adult AD patients.

Herb remedies, botanical extracts are common used in cosmetics and in local and systemic therapies of skin diseases. These therapies are very popular also among $\mathrm{AD}$ patients. Beside favourable effects their application is risky, as in case of an allergy the patient may respond to the particular plant with a hypersensitivity reaction. Some authors note that more controlled clinical studies are needed to determine the real efficacy and risks of plant therapies. Among side effects hypersensitivity reactions, cross reactions and photodermatitis have to be taken into account above all [30,31]. Fragrance mix I. and balsam of Peru belong to the most common environmental contact allergens in adult atopics. Thus, the popular aroma-therapies may flare the $\mathrm{AD}$ in case of hypersensitivity to certain components [4,5,31-33]. Only very few clinical trials have been published with herb products focused on adult AD therapy, the data are limited. Results [34] on 18 AD patients suggest that hyperforin (major constituent of Hypericum perforatum /Saint John's wort/) has antiiflammatory and antibacterial effect in $\mathrm{AD}$ : the intensity of the symptoms improved and the skin colonisation with Staphylococcus aureus reduced due to the therapy. Donsky et al. [35] demonstrated on 42 adult AD patients that a local treatment with a Mahonia aquifolium extract resulted significant improvement of the skin symptoms. Japanese herb Kampo drugs (Shiunko) has a long history in treatment of some inflammatory diseases. It may have antibacterial effects on Staphylococci, and so may be an effective treatment for $\mathrm{AD}$ [36]. Uehara et al. [37] suggest that the benefical effects of the oolong tea in adult $\mathrm{AD}$ may be the result of the antiallergic properties of tea polyphenols. Aromatherapeutic creams and popular volatile oils may provoke $\mathrm{AD}$ skin symptoms in case of hypersensitivity to the components. They may be risky also for therapeutists who perform the treatment (eg.massage) as well $[8,9]$.

Korean Medicine (KM) is used in many patients with AD. Kim et al. reported three pregnant women treated with KM (including acupuncture, herb medicine and herb wet dressing). According to the data, the skin symptoms improved after treatment. There was no hepatic or renal toxicity, nor were any adverse maternal or fetal, neonatal effects [38].

Traditional Chinese Medicine (TCM) is one of the most popular form of AT. Despite its widespread use, frequently neither therapeutists, nor patients are aware of the ways of applying TCM and of its possible toxicity. Young adults turn to TCM because it is thought to have no side effects, because of the inefficiency of medical treatments and for the recommendations of friends or family [39]. As TCM therapy, patients are given herb preparation (tea, brews, tablets, capsules, creams or ointments). Its terminology significantly differs from that of western medicine: atopic dermatitis as a diagnosis does not exist in that system. The bases of the pharmacological and immunological effects of TCM herb therapies in AD are unclear, but it is known that particular plants have anti-inflammatory effects. They relax smooth muscles, provoke peripheral vasodilation, have antimicrobial effects, influence prostaglandin metabolism, increase IL2 and IL3 receptor expression. Some various brews may consist 10-12 or even 30 plants, which are considered to have synergic effects in mixture. Several plants may contain pharmacological active agents applied in unknown concentrations. TCM may have some benefit for AD lesions, but the results are conflicting and reports on serious hepatotoxicity raise potential safety concerns. Well-designed, placebo-controlled clinical trials are warranted to evaluate the efficacy and safety of the use of $\mathrm{TCM}$ in adult $\mathrm{AD}$ [2,3,39-45].

The TCM - studies in children and adult AD gave contradictory results. The effects of TCM herb preparations on $\mathrm{AD}$ are: decrease of pruritus and improvement of skin symptoms. These effects are usually temporary and are common in patients, whose skin symptoms are not exudative and not superinfected. As side-effects, reversible liver enzyme increase, hepatotoxicity, reversible dilatative cardiomyopathy have been reported, mild abdominal pain and headache were observed. One should consider pregnancy, breastfeeding, childhood, liver and heart diseases as contraindication of TCM [12,39-44].

Acupuncture is one of the most popular AT. In dermatology, acupuncture has been found useful in acne, postherpetic neuralgia, psoriasis and some cases of urticaria. Its mechanism is not clear yet, it may exerts the effects by endorfin streaming and by steroid release induced by the activation of the hypothalamus-hypophysis axis $[46,47]$. Itch is one of the leading sympoms in $\mathrm{AD}$, treated in the practice mostly with antihistaminic. The quality of life of atopic patients is worsened most of all by strong pruritus: it may cause sleep disorder, problems in concentration, and social isolation, which, by triggering negative emotions again, produces a circulus vitiosus. There are very few reports on the efficacy of acupuncture in the itch of adult AD. Acupuncture alone or in conjunction with TCM decreases symptoms of AD but the evidence is confined to small studies of limited quality. Salameh et al. [46] reported an investigation on $20 \mathrm{AD}$ patients who were given a combined treatment of acupuncture and Chinese herbal medicine. The results suggest that this combination has a benefical effects on $\mathrm{AD}$ symptoms and may gives better results than Chinese herbal medicine alone. According to the data of Pfab et al., both acupuncture and cetirizine significantly reduced type I hypersensitivity itch in patients with $\mathrm{AD}$, compared with placebo [48,49]. Lee et al's preliminary results show, that acupressure for 4 weeks supressed pruritus and lichenification in adult $\mathrm{AD}$ patients [50].

In summary, 125 adult $\mathrm{AD}$ patients (91 women, 34 men) were involved in this study. 67 patients ( 52 women, 15 men) tried some kind of AT to treat AD their symptoms. The 67 patients had 104 attepts in all. According to the data in the literature, homeopathy and herb preparations were very popular among our patients to. Common therapies were different aloe vera products - however, we didn't find any data in the literature about it's efficacy in adult AD. Hypnotherapy and TCM were not used at all by our adult AD patients. Most popular AT were homeopathy (34\%), aloe vera products (27\%), herb brews (18)\%, and acupuncture (15\%). According to our patients' observations the skin symptoms of $8(12 \%)$ patients improved due to any alternative 
therapy, the skin symptoms of $8(12 \%)$ patients worsened by using AT and $83 \%$ of all attempts were inefficient.

\section{Conclusion}

Data about the efficacy of the alternative therapies in adult $\mathrm{AD}$ are very limited in the literature. Although some methods are recommended in some cases, the observations of our patients can confirm that most of the AT have no effects on AD symptoms. It is important, that $54 \%$ of our patients tried at least one AT: this result focuses the attention on the importance of the AT in the medical history of adult $\mathrm{AD}$ patients. Although we were able to depend only on the patients' own observation, the high number of the reported inefficient attempts and the high inefficiency-rate of the most popular methods are noteworthy. Alternative therapies alone or in combination should be considered in the background of non-responder $\mathrm{AD}$ to. The effects of the alternative methods should be evaluated in further studies with large patients cohorts, in comparison to standard medical therapeutic agents. Because of possible adverse effects or therapy resistance, clinicians should enquire about and encurage patients to give informations about any alternative therapies that are being used. Patients should be advised that AT have not undergone sufficient evaluation of efficacy or safety $[2,3]$. Due to the lack of evidence-based international standards and data, we can offer some methods only additionally, and not as a real alternative in the treatment of adult $\mathrm{AD}$.

\section{References}

1. Sandström, Falk MH, Faergemann J (2006) Atopic dermatitis in adults: does it disappear with age? Acta Derm Venereol 86: 135-139. [Crossref]

2. Sidbury R, Tom WL, Bergman JN, Cooper KD, Silverman RA, et al. (2014) Guidelines of care for the management of atopic dermatitis. J Am Acad Dermatol 71: 1218-1233. [Crossref]

3. Rubel D, Thirumoorthy T, Soebaryo W, Weng SCK, Gabriel TM, et al. (2013) Consensus guidelines for the management of atopic dermatitis: an Asian-Pacific perspective. J Dermatol 40: 160-171. [Crossref]

4. Torley D, Futamura M, Williams HC, Thomas KS (2013) What's new in atopic eczema? An analysis of systematic reviews published in 2010-2011. Clin Exp Dermatol 38: 449-456. [Crossref]

5. Ozkaya E (2005) Adult onset atopic dermatitis. J Am Acad Dermatol 52: 579-582. [Crossref]

6. Baron SE, Goodwin RG, Nicolau N (2005) Use of complementary medicine among outpatients with dermatologic conditions within Yorkshire and South Wales, United Kingdom. J Am Acad Dermatol 52: 589-594. [Crossref]

7. Simpson EL, Basco M, Hanifin J (2003) A cross sectional survey of complementary and alternative medicine use in patients with atopic dermatitis. Am J Cont Derm 14: 144-147. [Crossref]

8. Berke R, Singh A, Guralnick M (2012) Atopic dermatitis: an overview. Am Fam Physician 86: 35-42. [Crossref]

9. DiNicola C, Kekevian A, Chang C (2013) Integrative medicine as adjunc terapy in the treatment of atopic dermatitis - the role of traditional chinese medicine, dietary supplements and other modalities. Clinic Rev Allergy Immunol 44: 242-253. [Crossref]

10. Magin PJ, Adams J, Heading G, (2006) Complementary and alternative medicine therapies in acne, psoriasis and atopic eczema: results of a qualitative study of patient's experiences and perceptions. J Alt Compl Med 12: 451-457. [Crossref]

11. Jensen P (1990) Use of alternative medicine by patients with atopic dermatitis and psoriasis. Acta Derm Venereol 70: 421-424. [Crossref]

12. Tan HY, Zhang AL, Chen D, Xue CC, Lenon GB (2013) Chinese herbal medicine for atopic dermatitis: a systematic review. J Am Acad Dermatol 69: 295-304. [Crossref]

13. Witt CM, Lüdtke R, Baur R (2005) Homeopathic medical practice: long term results of a cohort study with 3981 patients. BMC Public Health 5: 115. [Crossref]

14. Itamura R (2007) Effect of homeopathic treatment of 60 Japanese patients with chronic skin disease. Complement Ther Med 15: 115-120. [Crossref]
15. Itamura R, Hosoya R (2003) Homeopathic treatment of Japanese patients with intractable atopic dermatitis. Homeopathy 92: 108-114. [Crossref]

16. Werfel T, Breuer K (2004) Role of food allergy in atopic dermatitis. Curr Opin Allergy Clin Immunol 4: 379-385. [Crossref]

17. Breuer K, Kapp A, Werfel T (2003) The impact of food allergy in patients with atopic dermatitis. Hautarzt 54: 121-129. [Crossref]

18. Seitz CS, Pfeuffer P, Raith P, Bröcker EB, Trautmann A (2008) Food allergy in adults: an over or underrated problem? Dtsch Arztebl Int 105: 715-23. [Crossref]

19. Sicherer SH, Sampson HA (2014) Food allergy: Epidemiology, pathogenesis, diagnosis and treatment. J Allergy Clin Immunol 133: 291-307. [Crossref]

20. Yun J, Katelaris CH (2009) Food allergy in adolescents and adults. Intern Med J 39: 475-478. [Crossref]

21. Nakamura H, Shimoi K, Kouda K (2003) An adult with atopic dermatitis and repeated short term fasting. J physiol Anthropol Appl Human Sci 22: 237-240. [Crossref]

22. Tanaka T, Kouda K, Kotani M, (2001) Vegetarian diet ameliorates symptoms of atopic dermatitis through reduction of the number of peripheral eosinophils and of PGE2 synthesis by monocytes. J Physiol Antropol 20: 353-361. [Crossref]

23. Kim KS, Nam HJ (2013) Detoxification combining fasting with fluid therapy for refractory cases of severe atopic dermatitis. Evid Based Complement Alternat Med. [Crossref]

24. Shenefelt PD (2000) Hypnosis in dermatology. Arch Derm 136: 393-399. [Crossref]

25. Kilpeläinen M, Koskenvuo M, Helenius H (2002) Stressful life events promote the manifestation of asthma and atopic diseases. Clin Exp Allergy 32: 256-263. [Crossref]

26. Raap U, Werfel T, Jaeger B (2003) Atopic dermatitis and psychological stress. Hautarzt 54: 925-929. [Crossref]

27. Kimata $H$ (2007) Increase in dermcidin-derived peptides in sweat of patients with atopic eczema caused by humorous video. J Psychosom Res 62: 57-59. [Crossref]

28. Kimata H (2003) Listening to Mozart reduces allergic skin wheal responses and in vitro allergen -specific Ig E production in atopic dermatitis patients with latex allergy. Behav Med 1: 15-19. [Crossref]

29. Stewart AC, Thomas SE (1995) Hypnotherapy as a treatment for atopic dermatitis in adults and children. Br J Dermatol 132: 778-783. [Crossref]

30. Reuter J, Wölfle U, Weckesser S, Schempp C (2010) Which plant for which skin diesase? Part 1: atopoc dermatitis, psoriasis, acne, condyloma, and herpes simplex. $J$ Dtsch Dermatol Ges 8: 788-796. [Crossref]

31. Reuter J, Merfort I, Schempp CM (2010) Botanicals in dermatology: an evidence based review. Am J Clin Dermatol 11: 247-267. [Crossref]

32. Pónyai GY, Hidvégi B, Németh I, Sas A, Temesvári E, et al. (2012) Environmental contact allergens in adult atopic dermatitis. Translational Science: from basic to clinical Immunology and Allergy, Pisa: Pacini Editore: 257-259.

33. Pónyai G, Hidvégi B, Németh I, Sas A, Temesvári E, et al. (2008) Contact and aeroallergens in adulthood atopic dermatitis. J Eur Acad Dermatol Venereol 22: 13461355. [Crossref]

34. Schempp CM, Hezel S, Simon JC (2003) Topical treatment of atopic dermatitis with Hypericum cream. A randomised, placebo controlled, double-blind half side comparison study. Hautarzt 54: 248-253. [Crossref]

35. Donsky H, Clarke D (2007) Reliéva a Mahonia aquifolium extract for the treatment of adult patients with atopic dermatitis. Am J Ther 14: 442-446. [Crossref]

36. Shimizu T (2013) Efficacy of kampo medicine in treating atopic dermatitis: an overview Evid Based Complement Alternat Med 260235 Epub 2013. dec 29. [Crossref]

37. Uehara M, Sugiura H, Sakurai K (2001) A trial of oolong tea in the management of recalcitrant atopic dermatitis. Arch Dermatol 137: 42-43. [Crossref]

38. Kim M, Yun Y, Kim Ks, Choi I (2013) Three cases of atopic dermatitis in pregnant women successfully treated with Korean medicine. Complement Ther Med 21: 512516. [Crossref]

39. Hon EK, Lee K, Tse HM, Lam LN, Tam KC, et al. (2004) A survey of attitudes to Tradicional Chinese Medicine in Hong Kong pharmacy students. Complement Ther Med 12: 51-53. [Crossref]

40. Sheehan MP, Rustin MH, Atherton DJ, Buckley C, Harris DW, et al. (1992) Efficacy of traditional Chinese herbal therapy in adult atopic dermatitis. Lancet 340: 13-17. [Crossref] 
41. Sheehan MP, Stevens H, Ostlere LS, Atherton DJ, Brostoff J, et al. (1995) Follow-up of adult patients with atopic eczema treated with Chinese herbal therapy for 1 year. Clin Exp Dermatol 20: 136-140. [Crossref]

42. Fung AY, Look PC, Chong LY, But PP, Wong E (1999) A controlled trial of traditional Chinese herbal medicine in Chinese patients with recalcitrant atopic dermatitis. Int $J$ Dermatol 38: 387-392. [Crossref]

43. Ferguson JE, Chalmers RJ, Rowlands DJ (1997) Reversible dilated cardiomyopathy following treatment of atopic eczema with Chinese herbal medicine. $\mathrm{Br} J$ Dermatol 136: 592-593. [Crossref]

44. Banerjee P, Xu XJ, Poulter LW, Rustin MH (1998) Changes in CD23 expression of blood and skin in atopic eczema after Chinese herbal therapy. Clin Exp Allergy 28: 306-314. [Crossref]

45. Gu S, Yang AW, Li CG, Lu C, Xue CC (2014) Topical application of Chinese herbal medicine for atopic eczema: a systematic review with a meta-analysis. Dermatology 228: 294-302. [Crossref]
46. Salameh F, Perla D, Solomon M, Gamus D, Barzilai A, et al. (2008) The effectiveness of combined chinese herbal medicine and acupuncture in the treatment of atopic dermatitis. J Alt Compl Med 14: 1043-1048. [Crossref]

47. Chen CJ, Yu HS (2003) Acupuncture, electrostimulation and reflex therapy in dermatology. Dermatol Ther 16: 87-92. [Crossref]

48. Pfab F, Huss-Marp J, Gatti A, Fuqin J, Athanasiadis GI, et al. (2010) Influence of acupuncture on type I hypersensitivity itch and the wheal and flare response in adults with atopic eczema - a blinded, randomized, placebo-controlled crossover trial. Allergy 65: 903-910. [Crossref]

49. Pfab F, Kirchner MT, Huss-Marp J, Schuster T, Schalock PC, et al. (2012) Acupuncture compared with oral antihistamine for type I hypersensitivity itch and skin response in adults with atopic dermatitis: a patient- and examiner-blinded, randomized, placebo controlled, crossover trial. Allergy 67: 566-573. [Crossref]

50. Lee KC, Keyes A, Hensley JR, Gordon JR, Kwasny MJ, et al. (2012) Effectiveness of acupressure on pruritus and lichenification associated with atopic dermatitis: a pilot trial. Acupunct Med 30: 8-11. [Crossref]

Copyright: (C2015 Ponyai G. This is an open-access article distributed under the terms of the Creative Commons Attribution License, which permits unrestricted use, distribution, and reproduction in any medium, provided the original author and source are credited. 